\title{
Two endemic species of Fimbristylis (Cyperaceae) new to the Flora of Eastern Ghats, southern India
}

\author{
M. Mahendra Nath' ${ }^{1}$, V.P. Prasad ${ }^{2 *}$ and K. Madhava Chetty ${ }^{1}$ \\ ${ }^{1}$ Department of Botany, Sri Venkateswara University, Tirupati, Andhra Pradesh - 517502, India. \\ ${ }^{2}$ Central National Herbarium, Botanical Survey of India, Botanic Garden P.O., Howrah - 711103, \\ West Bengal, India. \\ *E-mail: prasad_parur@yahoo.com
}

\begin{abstract}
Fimbristylis monospicula Govind. and F. uliginosa Hochst. ex Steud. are reported here for the first time from the Eastern Ghats of Andhra Pradesh. Descriptions of the plants and images of the specimens and their floral parts are provided.
\end{abstract}

Keywords: Andhra Pradesh, Eastern Ghats, Endemic Species, Fimbristylis

\section{Introduction}

A critical examination of some sedge specimens collected from Horsley hills in Chittoor district of Andhra Pradesh resulted in the identification of two interesting endemic species, Fimbristylis monospicula Govind. and F. uliginosa Hochst. ex Steud. The specimens were identified by referring relevant literature (Fischer, 1931; Govindarajalu, 1974) and by matching with the specimens available at $\mathrm{CAL}$ and $\mathrm{MH}$. A perusal of recent literature pertinent to the region (Pullaiah, 1997; Indira \& Raju, 2001; Raju \& Kesavulu, 2003) revealed that these two species were never been collected or reported from the entire range of Eastern Ghats so far. Fimbristylis monospicula is hitherto known to occur only in Karnataka and Tamil Nadu and F. uliginosa is restricted to Tamil Nadu. Hence, both are reported here as addition to the sedge flora of Eastern Ghats and the state of Andhra Pradesh. These two endemic sedges are usually found on hills in southermn India. Descriptions of the species, their phenology and distribution are provided along with images of the plants and their floral parts for easy identification.

Fimbristylis monospicula Govind., Proc. Indian Acad. Sci., B 79: 169, f. 4a-f. 1974; Karthik. et al., Fl. Ind. Enum. Monocot.: 53. 1989; V.P. Prasad \& N.P. Singh, Sedges Karnataka (J. Econ. Taxon. Bot., Addit. Ser. 21): 194. 2002.

Fig. 1a-f

Annual. Culms slender, tufted, $8-10 \mathrm{~cm}$ high, angled, 0.4-0.6 mm thick, hispid-hairy throughout. Leaves, shorter than culm, slender c. $1 \mathrm{~mm}$ wide, apex acute to acuminate, hispid-hairy throughout; sheaths rather glabrous with prominent veins; ligule absent. Inflorescence a solitary, terminal spikelet. Bracts usually glume-like, 2-3 mm long, hispid on the keel towards apex, often fall off as the spikelet mature. Spikelets ovoid, terete, 4-5 $\times$ 3-3.5 mm, apex obtuse-acute, yellowish brown to dark brown, many-flowered. Glumes somewhat thick, spirally imbricate, broadly ovate to suborbicular, c. $2.5 \times 2 \mathrm{~mm}$, apex obtuse, muticous; keel 3-veined. Rachilla shortly winged, excavated. Stamens 3; filaments elongate up to 2.8 $\mathrm{mm}$; anthers linear-oblong, c. $0.8 \mathrm{~mm}$ long. Style $c$. $1 \mathrm{~mm}$ long, pyramidally thickened at base, ciliate towards apex; stigmas 3, somewhat shorter or almost equal to the style, ciliate. Achenes obovoid, trigonous, c. $1 \times 0.6 \mathrm{~mm}$, base cuneate, apex truncate-obtus, prominently tubercled, yellowish brown; epidermal cells in 6-8 rows, transversely oblong.

Flowering \& fruiting: July

Distribution: Hills of Andhra Pradesh (reported here), Karnataka and Tamil Nadu; not common. Endemic.

Specimen examined: INDIA, Andhra Pradesh: Chittoor district, Horsley hills, 7.7.2016, Mahendra Nath SVUTY / HH-02934 (CAL).

Note: Fimbristylis monospicula is very similar to F. kingii but differs by its short habit and smaller floral parts and achenes. In F. kingii culms are up to $26 \mathrm{~cm}$ long, spikelets $5-12 \mathrm{~mm}$ long, glumes $3.8-4 \times 2.5-3 \mathrm{~mm}$, anthers c. $2 \mathrm{~mm}$ long, style $2-2.5$ 


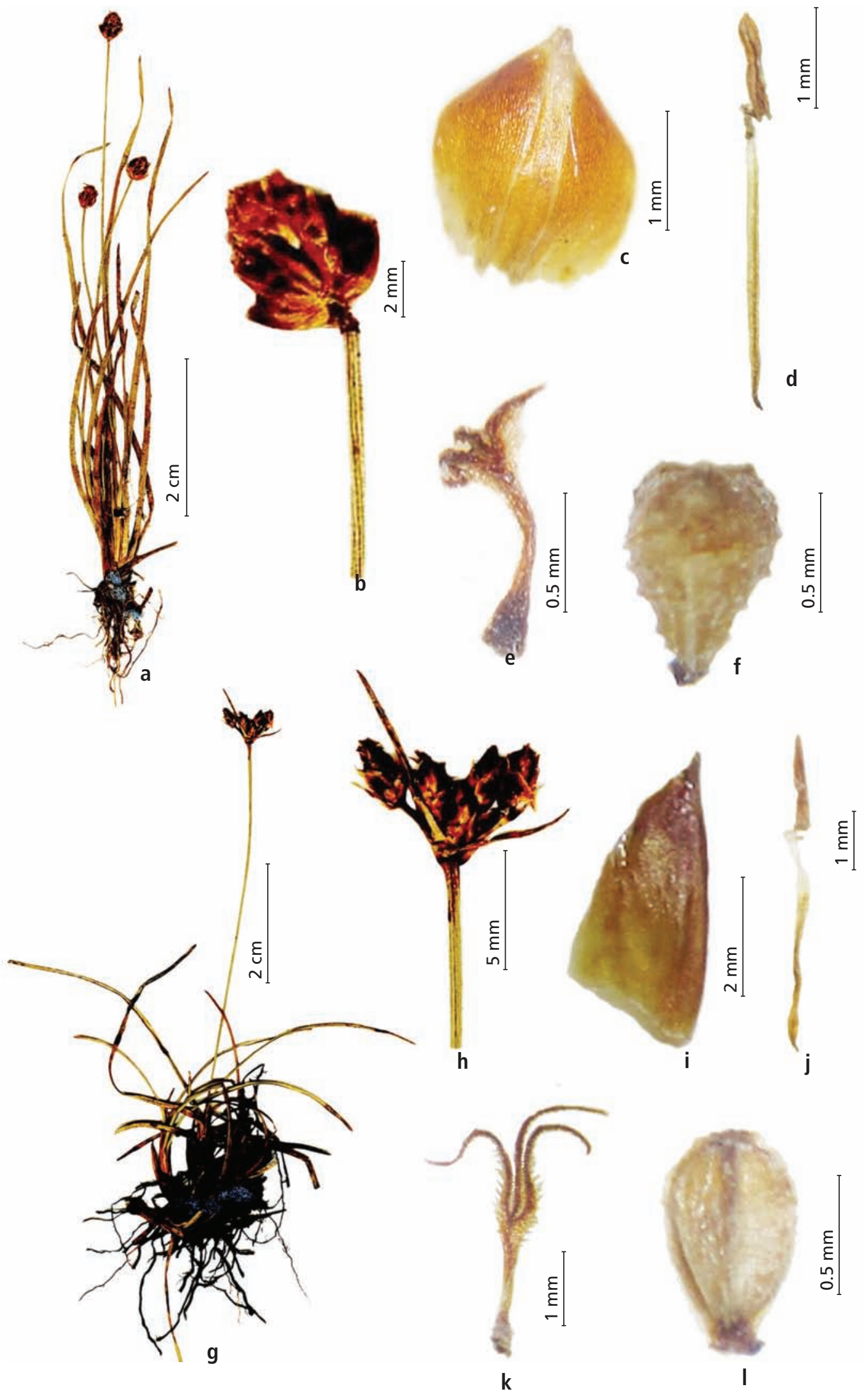

Fig. 1. a-f. Fimbristylis monospicula Govind.: a. Habit; b. Inflorescence; c. Glume; d. Stamen; e. Style; f. Achene (Mahendra Nath SVUTY/HH-02934); g-I. Fimbristylis uliginosa Hochst. ex Steud.: g. Habit; h. Inflorescence; i. Glume - side view; j. Stamen; k. Style; I. Immature achene (Mahendra Nath SVUTY/HH-02981). 
$\mathrm{mm}$ long and achenes 1.2-1.5 $\times$ c. $1 \mathrm{~mm}$. But in $F$. monospicula culms are $8-10 \mathrm{~cm}$ long, spikelets $4-5$ $\mathrm{mm}$ long, glumes c. $2.5 \times 2 \mathrm{~mm}$, anthers $c .0 .8 \mathrm{~mm}$ long, style $c .1 \mathrm{~mm}$ long and achenes $c .1 \times 0.6 \mathrm{~mm}$.

Fimbristylis uliginosa Hochst. ex Steud., Syn. Pl. Glumac. 2: 109. 1855; C.B. Clarke in Hook.f., Fl. Brit. India 6: 648. 1893; C.E.C. Fisch, Fl. Madras: 1660. 1931; Karthik. et al., Fl. Ind. Enum. Monocot.: 55. 1989.

Fig. 1g-1

Perennial with thick rhizome and slender culms, c. $10 \mathrm{~cm}$ high. Leaves shorter than culm, basal sheaths disintegrate into blackish fibres. Inflorescence a simple umbel. Involucral bracts hardly or slightly overtopping the inflorescence. Spikelets 5, somewhat congested or solitary, oblong-ovoid, c. $4 \times 1.8 \mathrm{~mm}$, apex acute. Glumes oblong-obovate, c. $4 \times 2 \mathrm{~mm}$, apex acute, glabrous; keel prominent, usually excurrent into a prominent mucro. Stamens 3; filaments elongate up to $4 \mathrm{~mm}$; anthers linear-oblong, c. $1.5 \mathrm{~mm}$ long. Style c. 1.5 $\mathrm{mm}$ long; stigmas 3, c. $2 \mathrm{~mm}$ long, ciliate. Achenes (immature), obovoid, trigonous, with flat ventral side and rounded dorsal sides, c. $0.9 \times 0.5 \mathrm{~mm}$, apex obtuse.

Flowering \& fruiting: May-October(-February).

Distribution: Hill stations of Andhra Pradesh (reported here) and Tamil Nadu. Endemic.

Specimens examined: INDIA, Andhra Pradesh: Chittoor district, Horsley hills, 8.7.2016, Mahendra Nath SVUTY/HH-02981 (CAL). Tamil Nadu: Coimbatore district, Anabetta, Bellaje, Kollegal, 7.10.1930, V. Narayanaswami 3838 (MH); Dindigul district, Poomparai, Palani, 15.5.1899, A.G. Bourne 1429 (MH); Tirunelveli district, Kannikatty, 23.2.1990, R. Gopalan $91684(\mathrm{MH})$.

Conservation Status: Fimbristylis monospicula and F. uliginosa are restricted to hill stations of southern India. The threat status of both the species has been provisionally assessed here as Data Deficient (DD) following IUCN Red List Categories and Criteria, version 3.1 (IUCN, 2012). However, more explorations in similar habitats at higher elevations in different states of southern India are required to know its necessary parameters to assess the exact threat category.

\section{Acknowledgements}

The authors are grateful to the Director, Botanical Survey of India, Kolkata and the Heads of Office, CAL, Howrah and $\mathrm{MH}$, Coimbatore for the facilities. Dr. W. Arisdason, Scientist, BSI, Kolkata, has gone through the manuscript and improved its quality. Mr. Anand Kumar, Botanical Assistant and Mr. Dinesh Sah, Artist, BSI, Kolkata kindly scanned specimens and prepared the plate. MMN is thankful to UGC, for the financial support in the form of UGC-BSR Fellowship.

\section{Literature Cited}

Fischer, C.E.C. 1931. Cyperaceae. Flora of the Presidency of Madras. Adlard \& Son, London. pp. 1620-1687.

Govindarajalu, E. 1974. Studies in Cyperaceae. XI. Novelties in Fimbristylis (L.) Vahl. Proc. Indian Acad. Sci., B 79: 160-172.

Indira, K. \& R.R.V. Raju 2001. Two new additions to the sedges, family Cyperaceae of Andhra Pradesh. J. Bombay Nat. Hist. Soc. 98: 497-499.

IUCN, 2012. IUCN Red List Categories and Criteria: Version 3.1. Second Edition. IUCN, Species Survival Commission, Gland. Available from http://www.iucnredlist.org/ (accessed 10 January 2015)

Pullaiah, T. 1997. Flora of Andhra Pradesh (India). Vol. 3. Monocotyledons. Scientific Publishers, Jodhpur.

Raju, R.R.V. \& M.C. Kesavulu 2003. Two new additions to the sedge (Cyperaceae) flora of Andhra Pradesh, India. J. Econ. Taxon. Bot. 27(Suppl.): 1181-1185.

Received: 18.3.2017

Revised and Accepted: 14.12.2017 